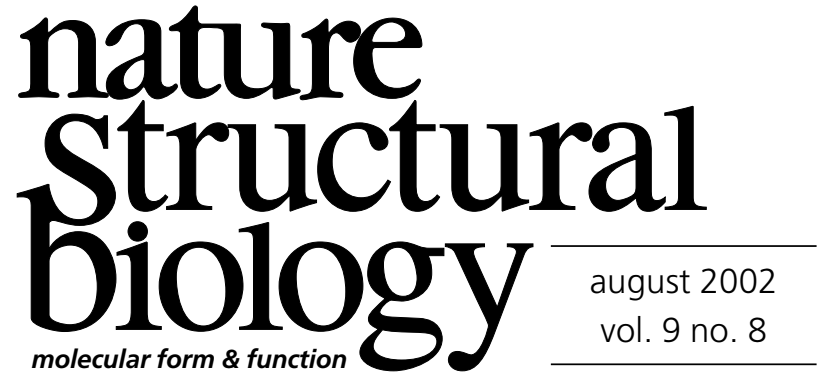

\section{Kid stuff}

A little boy sat in the middle of a row on a plane, his mother and sister to his left and two strangers to his right. "What's your job?" he asked one of them. "I am a worm scientist," said the woman with a smile. She was a C. elegans researcher. "Cool!" said the kid, proceeding to bombard her with questions.

With his curiosity about roundworms satisfied for the moment, he asked the woman's companion, "And what's your job?" The man replied pleasantly, "I am a structural biologist." The boy stared blankly, "Oh.” Then he thought of some more questions about worms.

How do you get a child interested in structural biology? First, it has to be explained in simple terms that they can appreciate, such as "I study what makes every living thing tick." Kids are curious but practical. They love to discover new things but sometimes have trouble understanding stuff that they can't put their fingers on. Worms they get with little explanation - but structural biology, DNA and proteins are more difficult concepts.

Now that summer is here, many scientist-parents are spending more time with their children - and perhaps looking for ways to introduce them to the world of cells, microbes and molecules, without taking them to lab. Kids are natural scientists, always wanting to know how and why. Small things and things that they can't see with their eyes alone should be no less interesting than big things. The trick is getting them to take the time to investigate; finding the right presentation to make the lesson fun is also key.

With young children, go for a walk and show them how to closely observe small objects - ants, spots on a leaf, or sand on the sidewalk. Buy an inexpensive microscope and show them tiny things. With older children, try an experiment - for example, help them extract DNA using stuff around the house (http://gslc.genetics.utah.edu/basic/howto/). Books with pictures of electron microscopy images help convey the variety of the microscopic world to youngsters of all ages. And all kids seem to love using computers - so, direct them to useful sites on the Internet.

Some of the most interesting science websites for children (or collections of sites) are listed in Table 1. While not all of these actually explain molecular biology, they will push kids toward asking questions that eventually lead to molecular answers. Cells Alive! is a particularly engaging site. It houses a gallery of cell images as well as information on microbiology (answering questions such as "Why aren't we knee deep in bacteria?"), immunology (describing how white blood cells react to trauma in "Anatomy of a Splinter") and cell biology (presenting "Cell Cams" that show, in real time over the course of a day, how quickly cancer cells and bacteria cells multiply). Another sure winner with kids is the Yuckiest Site on the Internet. Here you can discover (in the "Ask Wendell the Worm" section) why poison ivy makes you itch, how pain relievers work, and what causes bad breath. If you want to interest your child in DNA, RNA and proteins directly, then biology4kids.com, chem4kids.com, and the I Can Do That site are good choices - but note that the first two are geared toward older children.

Finding the time and resources to explain cellular, molecular and structural biology to children is a worthwhile endeavor. Not only is it imperative to educate young people about science, it is also important for scientists to learn to simplify complex concepts without distorting them completely. Seeing science through the eyes of a child can be refreshing for jaded scientists. Their questions remind us of why we entered science in the first place - because it's really cool.

\begin{tabular}{|ll|}
\hline \multicolumn{2}{|c|}{ Table 1 Some science sites for kids } \\
\hline - Cells Alive! & http://www.cellsalive.com \\
- Yuckiest Site on the Internet & http://yucky.kids.discovery.com/ \\
- Biology for Kids & http://www.biology4kids.com \\
- Chemistry for Kids & http://www.chem4kids.com \\
- I Can Do That & http://www.eurekascience.com/ \\
& ICanDoThat/ \\
- Cool Science for Curious Kids & http://www.hhmi.org/coolscience/ \\
- Microbe World & http://www.microbeworld.org/m/c/ \\
- Kid Sites Science & http://www.kidsites.com/ \\
& sites-edu/science.htm \\
- Science Netlinks & http://www.sciencenetlinks.com/ \\
- Life Science Resources & http://surfaquarium.com/ \\
& biology.htm \\
\hline
\end{tabular}

